\title{
Brevibacterium marinum sp. nov., isolated from seawater
}

\author{
Soon Dong Lee
}

Correspondence

Soon Dong Lee

sdlee@cheju.ac.kr
Department of Science Education, Cheju National University, Jeju 690-756, Republic of Korea

\begin{abstract}
A novel yellow-pigmented actinobacterium was isolated from seawater collected from Hwasun Beach in Jeju, Republic of Korea. A comparative analysis of the 16S rRNA gene sequence indicated that the organism, designated HFW- $26^{\top}$, was closely related to members of the genus Brevibacterium. As found for other species of the genus Brevibacterium, strain HFW-26 ${ }^{\top}$ possessed meso-diaminopimelic acid as the diagnostic cell-wall diamino acid, contained MK- $8\left(\mathrm{H}_{2}\right)$ as the major menaquinone, contained polar lipids that included diphosphatidylglycerol, phosphatidylglycerol, phosphatidylinositol and an unknown phospholipid, and had anteiso- $\mathrm{C}_{15: 0}$ and anteiso- $\mathrm{C}_{17: 0}$ as the predominant fatty acids. The $\mathrm{G}+\mathrm{C}$ content of the DNA was $71.4 \mathrm{~mol} \%$. The phylogenetically closest relative was Brevibacterium picturae DSM $16132^{\top}$ (99.0\% 16S rRNA gene sequence similarity). However, DNA-DNA hybridization of strain HFW-26 ${ }^{\top}$ showed $35.1-43.7 \%$ relatedness with respect to $B$. picturae DSM $16132^{\top}$. The novel isolate could be clearly distinguished from $B$. picturae DSM $16132^{\top}$ on the basis of some cultural, physiological and biochemical characteristics. A battery of phenotypic and genetic data obtained in this study suggest that strain HFW- $26^{\top}$ represents a novel species of the genus Brevibacterium, for which the name Brevibacterium marinum sp. nov. is proposed. The type strain is $\mathrm{HFW}-26^{\top}\left(=\mathrm{JBRI} 2001^{\top}=\right.$ KCTC $\left.19221^{\top}=\mathrm{DSM} 18964^{\top}\right)$.
\end{abstract}

The genus Brevibacterium, which was originally proposed by Breed (1953), is classified within the family Brevibacteriaceae, suborder Micrococcineae (Stackebrandt et al., 1997). At the time of writing, the following 15 species with validly published names, in addition to the type species Brevibacterium linens, remain within the genus: Brevibacterium antiquum, B. aurantiacum, B. permense (Gavrish et al., 2004), B. avium (Pascual \& Collins, 1999), B. casei, B. epidermidis (Collins et al., 1983), B. cerele (Ivanova et al., 2004), B. iodinum (Collins et al., 1980), B. luteolum (Wauters et al., 2003; Euzéby \& Tindall, 2004), B. mcbrellneri (McBride et al., 1993), B. otitidis (Pascual et al., 1996), B. paucivorans (Wauters et al., 2001), B. picturae (Heyrman et al., 2004), B. sanguinis (Wauters et al., 2004) and B. samyangense (Lee, 2006). While most of the species were isolated from dairy products, clinical specimens, poultry and soils, a few were recovered from marine environments, such as algae and beach sediment, as reported previously (Ivanova et al., 2004; Lee, 2006).

In the present study, an actinomycete isolated from a seawater sample collected at Hwasun Beach, Jeju, Republic of Korea, was investigated by means of a polyphasic

The GenBank/EMBL/DDBJ accession number for the 16S rRNA gene sequence of strain HFW-26 ${ }^{\top}$ is AM421807.

Transmission electron micrographs of cells of strain HFW-26 ${ }^{\top}$ are available as a supplementary figure with the online version of this paper. taxonomic approach. For bacterial isolation, aliquots of a seawater sample were directly deposited on starch-casein agar (Küster \& Williams, 1964) supplemented with $60 \%$ natural seawater instead of distilled water. A colony was further subcultured on marine agar 2216 (MA; Difco). The pure culture, designated strain $\mathrm{HFW}-26^{\mathrm{T}}$, was maintained at -20 and $-80{ }^{\circ} \mathrm{C}$ as a glycerol solution that included $20 \%(\mathrm{v} / \mathrm{v})$ distilled water and $60 \%(\mathrm{v} / \mathrm{v})$ seawater. For phenotypic comparisons and DNA-DNA hybridizations, B. picturae DSM $16132^{\mathrm{T}}$ was grown on trypticase soy agar (TSA; Difco) at $28{ }^{\circ} \mathrm{C}$ for 5 days.

Cell morphology and motility were observed by using phase-contrast and transmission electron microscopy, with cultures grown for $6,15,24,48$ and $72 \mathrm{~h}$ in trypticase soy broth (Difco) at $30{ }^{\circ} \mathrm{C}$. Growth was tested on yeast extractmalt extract agar (ISP 2 medium; Shirling \& Gottlieb, 1966), TSA and nutrient agar (Difco), with and without supplementation with $60 \%(\mathrm{v} / \mathrm{v})$ natural seawater, incubated for 5 days at $28{ }^{\circ} \mathrm{C}$. The growth temperature $(4-$ $40{ }^{\circ} \mathrm{C}$ ) was tested on TSA. The initial $\mathrm{pH}$ for growth (determined on MA) was in the range 4.1-12.1. $\mathrm{NaCl}$ tolerance for growth was studied using ISP 2 medium as the basal medium. The Gram stain was determined using a Color Gram 2 F kit (bioMérieux). Degradation of casein, cellulose, hypoxanthine, DL-tyrosine and xanthine was tested on MA. Hydrolysis of DNA and starch was examined on DNase test agar (Difco) and starch agar (Difco), 
respectively; after incubation for 5 days, the plates were flooded with $1 \mathrm{M} \mathrm{HCl}$ and iodine solution, respectively. Catalase and oxidase activities were checked as described previously (Lee, 2006). Other physiological and biochemical properties were determined using API Coryne and API ZYM strips (bioMérieux) according to the manufacturer's instructions. Strain HFW $-26^{\mathrm{T}}$ showed good growth on all media tested; the cells were non-motile rods $(0.6-0.9 \mu \mathrm{m}$ wide and 1.5-2.4 $\mu \mathrm{m}$ long) at exponential phase. In older cultures, the cells fragmented into short rods $(0.5-0.6 \mu \mathrm{m}$ wide and $0.7-1.0 \mu \mathrm{m}$ long) that occasionally occurred singly or, more often, in pairs or in chains. Transmission electron micrographs of cells of strain HFW- $26^{\mathrm{T}}$ are shown in Supplementary Fig. S1 (available with the online version of this paper). The $\mathrm{V}$-form arrangement was also observed when cells were studied using light and phase-contrast microscopy. Colonies were translucent, convex, smooth and circular with entire margins. The colony pigmentation was variable depending on the culture conditions: in the dark, colonies were white; in the light, colonies were bright yellow. Colonies of B. picturae DSM $16132^{\mathrm{T}}$ were white in colour, irrespective of the culture conditions. Data for other physiological and biochemical properties of strain HFW $-26^{\mathrm{T}}$ are given in the species description and Table 1.

The 16S rRNA gene sequencing studies were performed as described elsewhere (Lee, 2006). An almost-complete 16S rRNA gene sequence (1455 nt) for strain $\mathrm{HFW}-26^{\mathrm{T}}$ was determined in this study and compared with those of members of the genus Brevibacterium. A phylogenetic tree (Fig. 1) based on 16S rRNA gene sequences indicated that the organism belonged to the genus Brevibacterium: it formed a coherent cluster with B. picturae. This relationship was supported by a high bootstrap percentage (91\%) and was also found in the maximum-likelihood and maximum-parsimony trees. The phylogenetic neighbours were B. picturae ( $99.0 \%$ sequence similarity), B. aurantiacum $(98.4 \%)$ and B. antiquum (98.0\%). Strain HFW-26 ${ }^{\mathrm{T}}$ shared 16S rRNA gene sequence similarity values of 94.7$97.6 \%$ with respect to the type strains of the other recognized species of the genus Brevibacterium.

DNA-DNA hybridization was carried out as described by De Ley et al. (1970), as modified by Huß et al. (1983), using a Cary 100 Bio UV/Vis-spectrophotometer equipped with a Peltier-thermostatted $6 \times 6$ multicell changer and a temperature controller with an in situ temperature probe (Varian). Genomic DNA was isolated using a French pressure cell (Thermo Spectronic) and was purified by chromatography on hydroxyapatite as described by Cashion et al. (1977). Several species of the genus Brevibacterium have been found to have $99 \% 16 \mathrm{~S}$ rRNA gene sequence similarity with each other, but show DNADNA relatedness values that are below the $70 \%$ threshold required for delineating a genospecies (Wauters et al., 2001, 2003; Gavrish et al., 2004). Therefore, DNA-DNA hybridization for strain HFW-26 ${ }^{\mathrm{T}}$ was performed only with respect to the type strain of the phylogenetically closest species. The levels of DNA-DNA relatedness for strain HFW $-26^{\mathrm{T}}$ and B. picturae DSM $16132^{\mathrm{T}}$ were between 35.1 and $43.7 \%$ when strain HFW $-26^{\mathrm{T}}$ was used as the probe. The DNA G $+\mathrm{C}$ content of strain HFW $-26^{\mathrm{T}}$ was $71.4 \mathrm{~mol} \%$, as determined by HPLC (Mesbah et al., 1989).

Chemotaxonomic characteristics of strain $\mathrm{HFW}-26^{\mathrm{T}}$ were investigated as described previously (Lee, 2006) to determine the type of diamino acid in the cell wall (Staneck \& Roberts, 1974), the mycolic acids (Minnikin et al., 1980), the polar lipids (Minnikin et al., 1977) and the menaquinones (Kroppenstedt, 1985). Cells of strain HFW$26^{\mathrm{T}}$ were grown in trypticase soy broth for 3 days at $30^{\circ} \mathrm{C}$, with shaking at 170 r.p.m. After harvesting, the biomass was washed in distilled water and freeze-dried. The results

Table 1. Differential characteristics for strain $\mathrm{HFW}-26^{\top}$ and its phylogenetic neighbours

Strains: 1, HFW-26 $6^{\mathrm{T}}$; 2, B. antiquum VKM Ac- $2118^{\mathrm{T}}$ (Gavrish et al., 2004); 3, B. aurantiacum VKM Ac-2111 ${ }^{\mathrm{T}}$ (Gavrish et al., 2004); 4, B. picturae DSM $16132^{\mathrm{T}}$ (Heyrman et al., 2004; this study). +, Positive; -, negative.

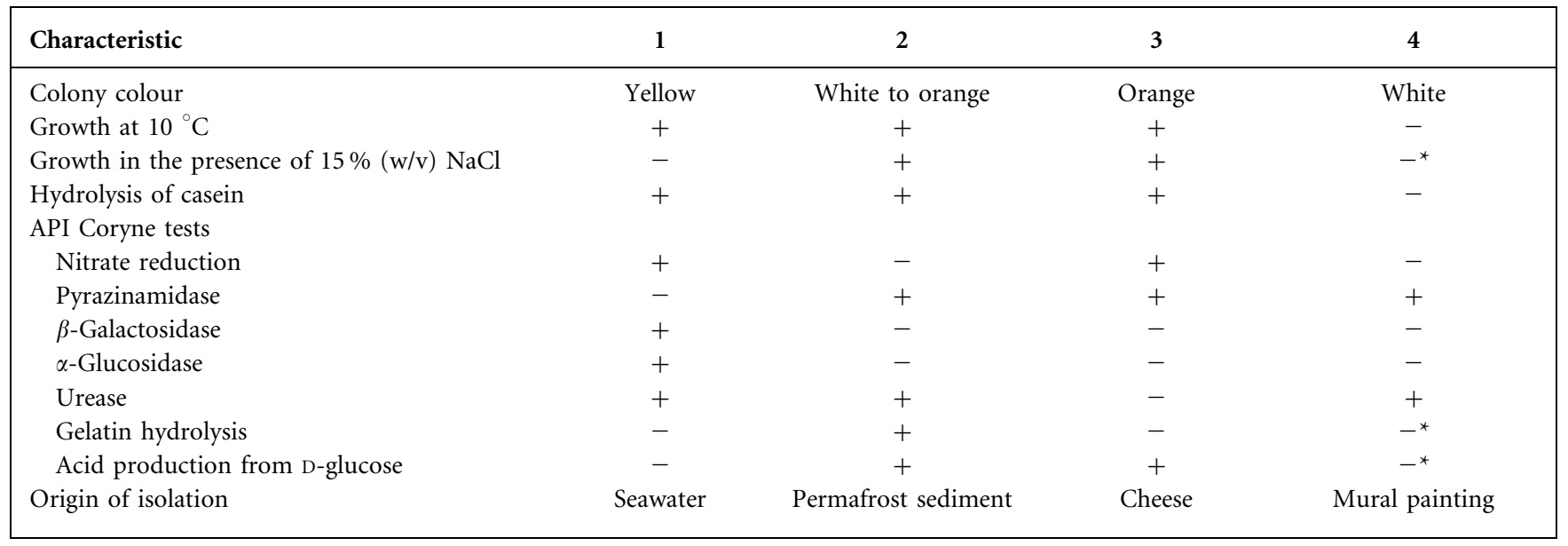

${ }^{\star}$ Result differs from that reported previously (Heyrman et al., 2004). 


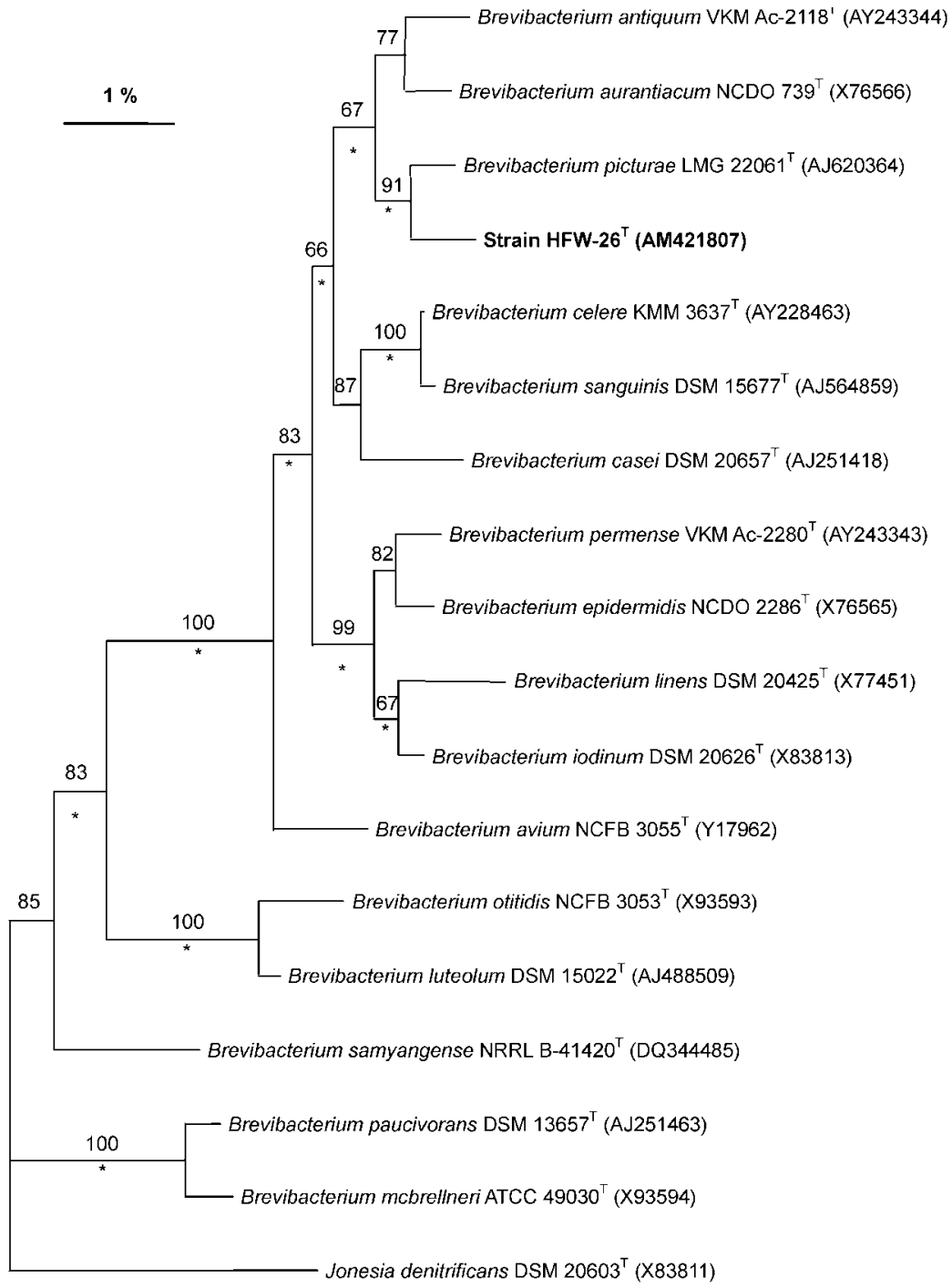

Fig. 1. Phylogenetic tree, based on $16 \mathrm{~S}$ rRNA gene sequences, showing the position of strain HFW-26 ${ }^{\top}$ within the family Brevibacteriaceae. The tree was constructed using the Jukes-Cantor model (Jukes \& Cantor, 1969) and the neighbour-joining method (Saitou \& Nei, 1987). Asterisks indicate branches that were also found in the maximum-likelihood (Felsenstein, 1981) and maximum-parsimony (Fitch, 1971) trees. Numbers at the nodes indicate percentages of bootstrap support (based on a neighbourjoining analysis of 1000 resampled data). Bar, 1 substitution per 100 nucleotide positions.

of the chemotaxonomic analyses of strain HFW $-26^{\mathrm{T}}$ are given in the species description. All of the chemotaxonomic characteristics were in accordance with the genus description (Collins et al., 1983). The cellular fatty acid methyl esters of the novel isolate and B. picturae DSM $16132^{\mathrm{T}}$ were prepared from cells grown on TSA for 3 days at $30{ }^{\circ} \mathrm{C}$ and analysed according to the instructions for the Sherlock Microbial Identification System (version 6; MIDI). The cellular fatty acid content of strain HFW- $26^{\mathrm{T}}$ conformed to the characteristic profile for the genus Brevibacterium and consisted of saturated, anteiso- and iso-methyl branched acids. The major components were anteiso- $\mathrm{C}_{15: 0}(41.2 \%)$, anteiso- $\mathrm{C}_{17: 0}(30.4 \%)$, and $\mathrm{C}_{18: 0}(12.0 \%)$. The main difference between strain HSW $-26^{\mathrm{T}}$ and B. picturae DSM $16132^{\mathrm{T}}$ was in relation to the proportion of $\mathrm{C}_{18: 0}$ present (Table 2).

Although strain HFW-26 ${ }^{\mathrm{T}}$ shared a high level of $16 \mathrm{~S}$ rRNA gene sequence similarity $(99.0 \%)$ with the type strain of $B$.
Table 2. Cellular fatty acid content (\%) of strain HFW- $-26^{\top}$ and its phylogenetically closest relative

Strains: $1, \mathrm{HFW}-26^{\mathrm{T}} ; 2$, B. picturae DSM $16132^{\mathrm{T}}$. Values that were less than $1 \%$ of total fatty acids have been omitted.

\begin{tabular}{|lrc|}
\hline Fatty acid & $\mathbf{1}$ & $\mathbf{2}$ \\
\hline Straight-chain fatty acids & & \\
$\mathrm{C}_{12: 0}$ & 2.9 & 1.3 \\
$\mathrm{C}_{16: 0}$ & 5.8 & 3.4 \\
$\mathrm{C}_{18: 0}$ & 12.0 & 3.0 \\
Branched fatty acids & & \\
iso-C $\mathrm{C}_{15: 0}$ & 3.2 & 5.8 \\
iso-C $\mathrm{C}_{16: 0}$ & 3.0 & 3.4 \\
iso- $\mathrm{C}_{17: 0}$ & 1.2 & 1.4 \\
anteiso-C & 41.2 & 49.7 \\
anteiso- $\mathrm{C}_{17: 0}$ & 30.4 & 29.6 \\
\hline
\end{tabular}


picturae, the relatively low level of DNA-DNA hybridization $(35.1-43.7 \%)$ revealed that the novel isolate does not belong to the species B. picturae (according to the $70 \%$ DNA-DNA similarity threshold recommended for the definition of bacterial genospecies; Wayne et al., 1987). Phenotypic features distinguishing strain $\mathrm{HFW}-26^{\mathrm{T}}$ from its phylogenetic neighbours are given in Table 1. Strain HFW $-26^{\mathrm{T}}$ can also be readily differentiated from the other recognized species of the genus Brevibacterium with reference to some physiological and biochemical properties (Wauters et al., 2003; Ivanova et al., 2004; Lee, 2006).

On the basis of the phenotypic and genotypic data presented here, strain HFW-26 ${ }^{\mathrm{T}}$ represents a novel species of the genus Brevibacterium, for which the name Brevibacterium marinum sp. nov. is proposed.

\section{Description of Brevibacterium marinum sp. nov.}

Brevibacterium marinum (ma.ri'num. L. neut. adj. marinum of the sea, marine).

Cells are Gram-positive, catalase-positive, oxidase-negative, non-motile, non-spore-forming rods that are long $(0.6-0.9 \mu \mathrm{m}$ wide and $1.5-2.4 \mu \mathrm{m}$ long) at exponential phase. As the culture ages, cells fragment into short rods (0.5-0.6 $\mu \mathrm{m}$ wide and $0.7-1.0 \mu \mathrm{m}$ long) that occasionally occur singly and, more often, in pairs or in chains. V-form arrangements are also observed. Colonies are translucent, convex, smooth and circular with entire margins. Colonial pigmentation is variable depending on the culture conditions: in the dark, colonies are white; in the light, colonies are bright yellow. The temperature range for growth is 10 $30{ }^{\circ} \mathrm{C}$, with an optimum of $30{ }^{\circ} \mathrm{C}$. No growth is observed at 4 or $37^{\circ} \mathrm{C}$. Growth occurs at initial $\mathrm{pH}$ values in the range 5.1-12.1. Growth occurs in the presence of up to $10 \%$ $\mathrm{NaCl}$. Casein and hypoxanthine are degraded, but cellulose, DL-tyrosine and xanthine are not degraded. Hydrolysis of DNA and starch is not observed. In the API Coryne system, the results for nitrate reduction, $\beta$ galactosidase, $\alpha$-glucosidase, urease and catalase are positive. Negative for the following enzyme activities: pyrazinamidase, pyrrolidonyl arylamidase, alkaline phosphatase, $\beta$-glucuronidase, $N$-acetyl- $\beta$-glucosaminidase and $\beta$-glucosidase (aesculin hydrolysis). Hydrolysis of gelatin is not observed. Acid production from carbohydrates (Dglucose, maltose, D-ribose, sucrose, D-xylose, D-mannitol, D-lactose and glycogen) is negative. In the additional tests in the API ZYM system, esterase (C4) and esterase lipase (C8) are weakly positive, but alkaline phosphatase, lipase (C14), leucine arylamidase, valine arylamidase, cysteine arylamidase, trypsin, $\alpha$-chymotrypsin, acid phosphatase, naphthol-AS-BI-phosphohydrolase, $\alpha$-galactosidase, $\beta$-glucosidase, $\alpha$-mannosidase and $\alpha$-fucosidase are negative. meso-Diaminopimelic acid is the diagnostic diamino acid in the cell wall. The polar lipids are diphosphatidylglycerol, phosphatidylglycerol and phosphatidylinositol, with an unknown phospholipid as a minor component. The major menaquinone is MK- $8\left(\mathrm{H}_{2}\right)$. Mycolic acids are absent. The major cellular fatty acids are anteiso- $\mathrm{C}_{15: 0}$, anteiso- $\mathrm{C}_{17: 0}$ and $\mathrm{C}_{18: 0}$. The DNA G+C content is $71.4 \mathrm{~mol} \%$.

The type strain, HFW $-26^{\mathrm{T}} \quad\left(=\mathrm{JBRI} \quad 2001^{\mathrm{T}}=\mathrm{KCTC}\right.$ $19221^{\mathrm{T}}=$ DSM $18964^{\mathrm{T}}$ ), was isolated from seawater from Hwasun Beach in Jeju, Republic of Korea.

\section{Acknowledgements}

This work was supported by the 21C Frontier Microbial Genomics and Application Center Program, Ministry of Science and Technology, Republic of Korea. The author is grateful to Dr Rüdiger Pukall (Deutsche Sammlung von Mikroorganismen und Zellkulturen, Braunschweig, Germany) for providing the type strain of B. picturae.

\section{References}

Breed, R. S. (1953). The families developed from Bacteriaceae Cohn with a description of the family Brevibacteriaceae. Riass Commun VI Congr Int Microbiol Roma 1, 10-15.

Cashion, P., Holder-Franklin, M. A., McCully, J. \& Franklin, M. (1977). A rapid method for base ratio determination of bacterial DNA. Anal Biochem 81, 461-466.

Collins, M. D., Jones, D., Keddie, R. M. \& Sneath, P. H. A. (1980). Reclassification of Chromobacterium iodinum (Davis) in a redefined genus Brevibacterium (Breed) as Brevibacterium iodinum nom. rev., comb. nov. J Gen Microbiol 120, 1-10.

Collins, M. D., Farrow, J. A. E., Goodfellow, M. \& Minnikin, D. E. (1983). Brevibacterium casei sp. nov. and Brevibacterium epidermidis sp. nov. Syst Appl Microbiol 4, 388-395.

De Ley, J., Cattoir, H. \& Reynaerts, A. (1970). The quantitative measurement of DNA hybridization from renaturation rates. Eur $J$ Biochem 12, 133-142.

Euzéby, J. P. \& Tindall, B. J. (2004). Status of strains that contravene Rules 27(3) and 30 of the Bacteriological Code. Request for an Opinion. Int J Syst Evol Microbiol 54, 293-301.

Felsenstein, J. (1981). Evolutionary trees from DNA sequences: a maximum likelihood approach. J Mol Evol 17, 368-376.

Fitch, W. M. (1971). Toward defining the course of evolution: minimum change for a specific tree topology. Syst Zool 20, 406-416.

Gavrish, E., Krauzova, V. I., Potekhina, N. V., Karasev, S. G., Plotnikova, E. G., Altyntseva, O. V., Korosteleva, L. A. \& Evtushenko, L. I. (2004). Three new species of brevibacteria, Brevibacterium antiquum sp. nov., Brevibacterium aurantiacum sp. nov., and Brevibacterium permense sp. nov. Microbiology (English translation of Mikrobiologiia). 73, 176-183.

Heyrman, J., Verbeeren, J., Schumann, P., Devos, J., Swings, J. \& Vos, P. D. (2004). Brevibacterium picturae sp. nov., isolated from a damaged mural painting at the Saint-Catherine chapel (Castle Herberstein, Austria). Int J Syst Evol Microbiol 54, 1537-1541.

Huß, V. A. R., Festl, H. \& Schleifer, K. H. (1983). Studies on the spectrophotometric determination of DNA hybridization from renaturation rates. Syst Appl Microbiol 4, 184-192.

Ivanova, E. P., Christen, R., Alexeeva, Y. V., Zhukova, N. V., Gorshkova, N. M., Lysenko, A. M., Mikhailov, V. V. \& Nicolau, D. V. (2004). Brevibacterium celere sp. nov., isolated from degraded thallus of a brown alga. Int J Syst Evol Microbiol 54, 2107-2111.

Jukes, T. H. \& Cantor, C. R. (1969). Evolution of protein molecules. In Mammalian Protein Metabolism, pp. 21-132. Edited by H. N. Munro. New York: Academic Press. 
Kroppenstedt, R. M. (1985). Fatty acid and menaquinone analysis of actinomycetes and related organisms. In Chemical Methods in Bacterial Systematics, pp. 173-199. Edited by M. Goodfellow \& D. E. Minnikin. London: Academic Press.

Küster, E. \& Williams, S. T. (1964). Selection of media for isolation of streptomycetes. Nature 202, 928-929.

Lee, S. D. (2006). Brevibacterium samyangense sp. nov., an actinomycete isolated from a beach sediment. Int J Syst Evol Microbiol 56, 1889-1892.

McBride, M. E., Ellner, K. M., Black, H. S., Clarridge, J. E. \& Wolf, J. E. (1993). A new Brevibacterium sp. isolated from infected genital hair of patients with white piedra. J Med Microbiol 39, 255-261.

Mesbah, M., Premachandran, U. \& Whitman, W. B. (1989). Precise measurement of the $\mathrm{G}+\mathrm{C}$ content of deoxyribonucleic acid by highperformance liquid chromatography. Int J Syst Bacteriol 39, 159-167.

Minnikin, D. E., Alshamaony, L. \& Goodfellow, M. (1977). Differentiation of Mycobacterium, Nocardia, and related taxa by thin layer chromatographic analysis of whole-cell methanolysates. J Gen Microbiol 88, 200-204.

Minnikin, D. E., Hutchinson, I. G., Caldicott, A. B. \& Goodfellow, M. (1980). Thin layer chromatography of methanolysates of mycolic acid-containing bacteria. J Chromatogr 188, 221-233.

Pascual, C. \& Collins, M. D. (1999). Brevibacterium avium sp. nov., isolated from poultry. Int J Syst Bacteriol 49, 1527-1530.

Pascual, C., Collins, M. D., Funke, G. \& Pitcher, D. G. (1996). Phenotypic and genotypic characterization of two Brevibacterium strains from the human ear: description of Brevibacterium otitidis sp. nov. Med Microbiol Lett 5, 113-123.
Saitou, N. \& Nei, M. (1987). The neighbor-joining method: a new method for reconstructing phylogenetic trees. Mol Biol Evol 4, 406-425.

Shirling, E. B. \& Gottlieb, D. (1966). Methods for characterization of Streptomyces species. Int J Syst Bacteriol 16, 313-340.

Stackebrandt, E., Rainey, F. A. \& Ward-Rainey, N. L. (1997). Proposal for a new hierarchic classification system, Actinobacteria classis nov. Int J Syst Bacteriol 47, 479-491.

Staneck, J. L. \& Roberts, G. D. (1974). Simplified approach to identification of aerobic actinomycetes by thin-layer chromatography. Appl Microbiol 28, 226-231.

Wauters, G., Charlier, J., Janssens, M. \& Delmée, M. (2001). Brevibacterium paucivorans sp. nov., from human clinical specimens. Int J Syst Evol Microbiol 51, 1703-1707.

Wauters, G., Avesani, V., Laffineur, K., Charlier, J., Janssens, M., Van Bosterhaut, B. \& Delmée, M. (2003). Brevibacterium lutescens sp. nov., from human and environmental samples. Int $J$ Syst Evol Microbiol 53, 1321-1325.

Wauters, G., Haase, G., Avesani, V., Charlier, J., Janssens, M., Broeck, J. V. \& Delmée, M. (2004). Identification of a novel Brevibacterium species isolated from humans and description of Brevibacterium sanguinis sp. nov. J Clin Microbiol 42, 2829-2832.

Wayne, L. G., Brenner, D. J., Colwell, R. R., Grimont, P. A. D., Kandler, O., Krichevsky, M. I., Moore, L. H., Moore, W. E. C., Murray, R. G. E. \& other authors (1987). International Committee on Systematic Bacteriology. Report of the ad hoc committee on reconciliation of approaches to bacterial systematics. Int $J$ Syst Bacteriol 37, 463-464. 